\title{
HEINONLINE
}

Citation: 97 Judicature 196 2013-2014

Content downloaded/printed from

HeinOnline (http://heinonline.org)

Thu Aug 21 10:15:39 2014

-- Your use of this HeinOnline PDF indicates your acceptance of HeinOnline's Terms and Conditions of the license agreement available at http://heinonline.org/HOL/License

-- The search text of this PDF is generated from uncorrected OCR text.

-- To obtain permission to use this article beyond the scope of your HeinOnline license, please use:

https://www.copyright.com/ccc/basicSearch.do?

\&operation $=$ go\&search $T y p e=0$

\&lastSearch $=$ simple\&all $=$ on\&titleOrStd $N o=0022-5800$

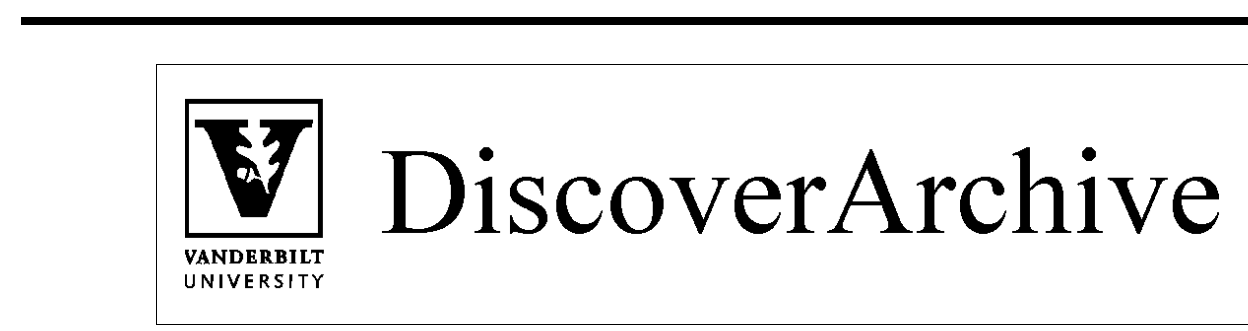

Retrieved from DiscoverArchive, Vanderbilt University's Institutional Repository

This work was originally published as Tracey E. George and Margaret S.

Williams, Venue Shopping: The Judges of the U.S. Judicial Panel on Multidistrict Litigation in 97 Judicature 196 2013-2014. 


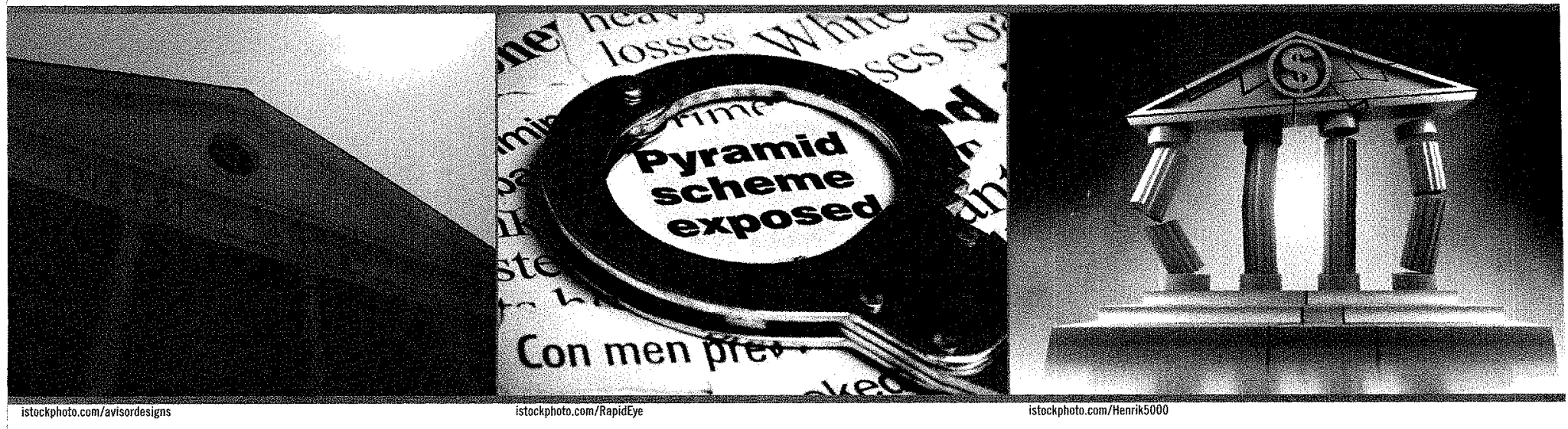

\title{
VENUE SHOPPING
}

\section{The Judges of the U.S. Judicial Panel on Multidistrict Litigation}

\author{
The United States Judicial Panel on Multidistrict Litigation is one of a small number of special judicial \\ bodies. The MDL Panel is a powerful judicial institution; for all practical purposes, it controls where many \\ of the most far-reaching private civil actions will be resolved. The significance of the MDL Panel's work \\ underscores the value of knowing more about the judges who exercise such substantial authority.
}

\section{by TRACEY E. GEORGE and MARGARET S. WILLIAMS}

A cosmetic company offers a moisturizer to fight the signs of aging; a pharmaceutical lab creates a generic version of a steroid; and a large socialnetworking website makes its initial public offering. While seemingly unrelated, these three events are all part of the world of complex litigation in federal courts. Each eventually produces thousands of separate lawsuits in multiple federal districts. The civil actions arising from each commercial activity share many of the same facts, parties, and issues. The simultaneous independent litigation of these related actions would not only be inefficient but also poses the risk of inconsistent decisions as different judges rule on the same legal questions. This is where the United States Judicial Panel on Multidistrict Litigation (MDL Panel) enters the picture.

The MDL Panel may transfer factu- ally related actions filed in different federal districts to a single judge in any federal district for consolidated pretrial litigation. ${ }^{1}$ The chief justice selects the seven members of the MDL Panel, also known as the JPML, from the district and circuit courts. These seven judges have substantial discretion in deciding whether to consolidate, where to transfer consolidated suits, and who will manage the consolidated multidistrict action (or MDL). ${ }^{2}$ While a transferred case theoretically returns to the transferor judge for trial, nearly all cases are resolved in the transferee court. ${ }^{3}$ Yet, the MDL Panel is not well known outside the circle of attorneys and parties who appear before it.

The relative obscurity of the MDL process belies its importance. If a manufacturer produces a harmful product, an airplane crashes, or a public corporation loses a large amount of money, then multidistrict litigation is a natural consequence. The Panel's docket reads like a laundry list of the most important lawsuits of the last half-century, including securities and derivative lawsuits related to the collapse of financial services firm Lehman Brothers and to the Ponzi scheme of Bernie Madoff; consumer protection claims involving thousands of plaintiffs and millions of dollars; products liability actions, including more than 40,000 asbestos cases and thou-

1. 28 U.S.C. $\$ 1407(a)$.

2. Margaret S. Williams \& Tracey E. George, Who Will Manage Complex Civil Litigation? The Decision to Transfer and Consolidate Multidistrict Litigation, 10 J. EMP. LEGAL STUD. 424 (2013).

3. See Emery G. Lee, Margaret S. Williams, Richard A. Nagareda, Joe S. Cecil, Thomas E. Willging \& Kevin M. Scott, The Expanding Role of Multidistrict Consolidation in Federal Civil Litigation: An Empirical Investigation, Working Paper (2012) (detailing how, when, and where MDL cases are resolved). 
sands of silicone gel breast implant suits; common disasters like the BP oil spill in the Gulf of Mexico and the Union Carbide chemical plant disaster in Bhopal, India; and nearly every air crash claim filed in federal court. These MDLs illustrate the scope and scale of multidistrict litigation in federal courts.

The raw number of cases, claims, parties, and dollars alone would make the MDL Panel a significant subject of study, but the impact of those cases reaches even farther. Because the lawsuits are among the most high-profile federal civil actions, their disposition influences the public's perception of the civil justice system and impacts the development of public policy in the related substantive and procedural areas of law. The handling and resolution of these disputes affect large numbers of individuals and alter the behavior of corporations, federal agencies, state governments, and law firms.

The significance of the MDL Panel's work underscores the value of knowing more about the judges who exercise such substantial authority. The Panel's composition also may help us to better understand its decisions. In light of the importance of the MDL Panel and its rulings, the current article looks

4. Philip C. Neal \& Perry Goldberg, The Electrical Equipment Antitrust Cases: Novel Judicial Administration, 50 A.B.A. JoURNAL 621 (1964).

5. 28 U.S.C. $\$ 1407(d)$.

6. See John G. Heyburn, $A$ View From the Panel: Part of the Solution, 82 TuL. L. REv. 2225, 2227 (2008).

7. See, e.g., Rodney Mott, Spencer Albright \& Helen R. Semmerling, Judicial Personnel, 167 ANNALS 143 (1933).

8. The most recent of these articles appeared in 2011. Sheldon Goldman, Sara Schiavoni \& Elliott Slotnick, Obama's Judiciary at Midterm, 94 JUDICATURE 262 (2011).

9. See, e.g., Susan Carbon, Pauline Houlden \& Larry Berkson, Women on the State Bench: Their Characteristics and Attitudes about Judicial Selection, 65 Judicature 294 (1982); Margaret S. Williams, In a Different Path: The Process of Becoming a Judge for Women and Men, 90 JUDICATURE 104 (2006).

10. See, e.g. Christina L. Boyd, Lee Epstein \& Andrew D. Martin, Untangling the Causal Effects of Sex on Judging, 54 AM. I. PoL. Scl. 5389 (2010).

11. Stephanie Francis Ward, Women Should be Among Lead Lawyers in IUD Case, Federal Judge Says, A.B.A. JouRnal (May 20, 2013, 1:00 PM), http://www.abajournal.com/news/article/ iud_litigation_needs_some_women_as_lead_ lawyers_says_federal_judge/. at the Panel's membership since its creation, identifying significant patterns in the judges' backgrounds and experiences.

\section{The Creation of the U.S. Judicial Panel on Multidistrict Litigation}

In the early $1960 \mathrm{~s}, 1,880$ civil antitrust lawsuits were filed against a group of electrical equipment manufacturers in 35 judicial districts from coast to coast. ${ }^{4}$ The suits involved more than 25,000 claims seeking treble damages from defendants, who had previously pled guilty or been convicted of criminal anti-trust violations. These "electrical equipment" lawsuits, as they became known, threatened to overwhelm the federal trial courts. The sheer number of suits was staggering, but the cases shared in common a set of complex substantive and procedural issues.

The Judicial Conference of the United States created a new subcommittee in 1962-the Coordinating Committee for Multiple Litigation of the United States District Courtsto manage the pretrial stages of the electrical equipment litigation. The Committee established a centralized national pretrial process with the voluntary participation of all parties and judges. Despite some initial skepticism, the coordinated pretrial litigation was considered a great success. In 1965, Chief Justice Earl Warren and the Conference proposed the permanent establishment of a judicial panel with the power to transfer civil actions involving common questions of fact to a single district for consolidated pretrial proceedings. Three years later, Congress created the U.S. Judicial Panel on Multidistrict Litigation.

The MDL statute provides that "[t]he judicial panel on multidistrict litigation shall consist of seven circuit and district judges designated from time to time by the chief justice of the United States, no two of whom shall be from the same circuit." Beyond that, the statute leaves much of its implementation to the Panel itself as well as to the chief justice. Panel tenure, for example, is not set by statute; Chief Justice Warren suggested that no appointee should serve for more than three years. But the first seven members stayed on for an average of 10 years. Chief Justice William Rehnquist in 2000 adopted a practice of appointing panelists for staggered seven-year terms, and Chief Justice John W. Roberts Jr. has continued that practice. ${ }^{6}$ The statute did provide for the selection of a Panel chair, who is also appointed by the chief justice. The statute allows a great deal of latitude in the choice of judges who may serve on the Panel. The next section provides some context for why scholars study the attributes and background of judges.

\section{The Personal Attributes and Social Background of Judges}

Court research dating back to at least the 1930s has focused on the individuals sitting on the bench. ${ }^{7}$ In 1978, Sheldon Goldman (later joined by Elliot Slotnick and others) began a series of federal judicial selection articles in Judicature profiling judges appointed during the prior two years, comparing the gender, race, occupation, education, and party of judges selected by the sitting president to those appointed by past presidents. ${ }^{8}$ State-court scholars have conducted similar studies on state judges.?

Judicial background is not merely descriptively interesting but it is also substantively important to the extent that a judge's attributes and experiences may affect her or his decisions. Numerous studies have found individual characteristics, to varying degrees and in different contexts, influence judicial decisions. ${ }^{10}$ The fact that background may affect decision making is not lost on judges in the MDL process. In the Mirena IUD multidistrict litigation, for example, transferee Judge Cathy Seibel advised the all-male group of lawyers seeking to serve as lead plaintiffs' counsel to include a woman in their group in light of the nature of the litigation. ${ }^{11}$

The small-group dynamics of the Panel would seem an ample opportunity for background characteristics to influence the group's decision. In 
fact, Congress created the Panel in order to capitalize on the fact that judges with experience in complex litigation would be better able to assess whether related civil suits should be consolidated for pretrial litigation. But complex litigation experience surely is not shared evenly across the federal judiciary. First, there was no precedent for such experience prior to the 1960s, at least not as a judge. Moreover, the judges who gained this experience came to the judiciary with a diverse set of background characteristics. By looking at the Panel over time, we can examine how important experience is relatively, and if there is a pattern in which judges gained experience with complex litigation.

The chief justice's authority to select MDL Panel judges adds another layer to the current study. The chief justice appoints Article III judges to serve in various capacities beyond their principal role, including service on judicial bodies. His largest number of appointments is to the committees of the U.S. Judicial Conference. $^{12}$ Judicial Conference Committees and Subcommittees advise the Conference, act on behalf of the Conference and recommend changes to rules of procedure and practice such as the Rules of Evidence and the Rules of Civil Procedure. ${ }^{13}$ The JPML's predecessor was a Conference Subcommittee, for example. The Committees' actions, like those of the MDL Panel, shape the nature of litigation in federal courts. The chief justice's unilateral power to appoint judges to both bodies creates an opportunity to influence that litigation.

\section{The Characteristics \\ of the MDL Panel Members}

Who has served on the MDL Panel? The characteristics of the panelists obviously tell us a great deal about the court as a descriptive matter but also have implications for its operation and public perception. We examine the attributes and social background, judicial experience, and appointing president and chief justice for the 46 MDL Panel judges who have served from the Panel's creation in 1968 through the end of 2012.

In order to put the MDL Panel's composition in context, we need to compare it to a relevant benchmark. Our first benchmark is the population of 2,417 judges who have served on Article III courts from 1968 to $2012 .{ }^{14}$ Almost all of these judges were eligible for appointment to the MDL Panel. But we recognize that not all of these judges were equally willing or able to take on additional responsibilities outside their home courts. For a second benchmark, we looked at another, much larger procedural body appointed by the chief justice: the Judicial Conference Committees. The last three chief justices have appointed a total of 861 judges to at least one Judicial Conference Committee. ${ }^{15} \mathrm{~A}$ judge may, but is not required to, serve on both a Conference Committee and a special body like the JPML. From 1971 through 2012, more than half of the MDL Panel had also served on a Conference Committee (27, or $59 \%)^{16}$

A more detailed look at MDL Panel judges may tease out what charac-

12. Dawn M. Chutkow, Policy Control, Political Entrepreneurs, and the Courts: Judicial Conference Committee Appointments, Working Paper (2012); Russell Wheeler, John Roberts Appoints Judges to More Than the FlSA Court, Brookings INSTITUTE (Aug. 8, 2013), http://www.brookings.edu/research/articles/2013/08/08-johnroberts-judges-appointees-wheeler; RUSSELL WheEler \& Gordon Bermant, Federal Court GOVERNANCE 10-19 (1994).

13. United States Courts, Judicial Conference of the United States: Committees, http://www. uscourts.gov/FederalCourts/Judicialconference/Committees.aspx.

14. In addition to the 94 district courts, 13 appellate courts, the Supreme Court, the Customs Court, the Court of International Trade, Court of Customs and Patent Appeals, and the Court of Claims are all included in this analysis. Of the 2,371 judges who served on one of those courts during this period, 218 served on two courts and 16 judges served on three Article III courts. Several judges served on multiple courts at the same time, including those appointed to the Eastern and Western districts of Missouri and the Western, Eastern, and Northern Districts of Oklahoma. Other judges served on multiple courts consecutively. Judges appointed to multiple courts simultaneously are assigned to a single court for purposes of calculating the descriptive statistics about the MDL Panel and the Conference Committees. All information was obtained from the Federal Judicial Center Federal Judicial History Database.

15. Our committee membership data is based teristics are more likely to be held by Panel members than by the rest of the judiciary. Table 1 lists the judges who have served on the Panel, the judges' tenure on the Panel, and who served as the Panel chair during that tenure. ${ }^{17}$

Our MDL Panel database includes detailed information about all Article III judges serving from 1968 through 2012, including their biographical data, tenure on the bench, service on Judicial Conference Committees and the MDL Panel, and experience with MDL cases. The database relies on various sources including the Federal Judicial Center (F]C) Federal Judicial History Office Biographical Database, reports of the Administrative Office of the U.S. Courts, the webpage of the MDL Panel, and MDL Panel opinions and orders. ${ }^{18}$

\section{Appointing Chief Justice}

Chief justices control selection to Judicial Conference Committees as well as to special judicial bodies like the MDL Panel. Variation in the composition, therefore, may may be due to a chief justice's preferences. Only four men, all Republican presiden-

on appointments since 1971, the first year when data are available. Some of these 861 judges served on more than one committee, and others served only as chair of a committee and not as a member. For a basic explanation of the Judicial Conference Committees, see Administrative OfFice of ThE U.S. Courts, The Federal, Court SYSTEM IN THE UNITED STATES: AN INTRODUCTION FOR JUDGES AND JUDICIAL ADMINISTRATORS IN OTHER COUNTRIES 38-39 (Washington, D.C.: Article III Judges Division, Office of Judges Programs, Administrative Office of the U.S. Courts 2000). The data were provided by the Administrative Office of the U.S. Courts. We thank Ellen Gerdes for her assistance.

16. Terms of service on the MDL Panel and the Conference Committees vary in length, and neither is capped by law but instead is within the discretion of the appointing chief justice. Panelists were initially appointed without fixed terms, but now the chief justice asks them to serve for seven years. Likewise the Conference Committee appointments vary in both expected duration (with some appointments listed as "Open Term") and in actual duration (with some judges stepping down before the expiration of their appointments). Because there is no clear term limit for either set of appointments, we do not control for term length.

17. Table 1 is recreated from Williams \& George, supra note 2 .

18. While there is information about education and some limited information about professional background (e.g. "private practice"), detail on these characteristics is insufficient for analysis. 
Members of the U.S. Judicial Panel on Multidistrict Litigation (Appointed by U.S. Supreme Court Chief Justice from 1968 to 2012)

\begin{tabular}{|c|c|c|c|c|c|c|}
\hline Judge & $\begin{array}{l}\text { Appointing } \\
\text { President }\end{array}$ & $\begin{array}{l}\text { Home } \\
\text { Court }\end{array}$ & $\begin{array}{l}\text { Appointed } \\
\text { to Panel }\end{array}$ & $\begin{array}{l}\text { Appointing } \\
\text { Chief Justice }\end{array}$ & $\begin{array}{l}\text { Resigned } \\
\text { from Panel }\end{array}$ & $\begin{array}{l}\text { Chair } \\
\text { Appointment }\end{array}$ \\
\hline Alfred P. Murrah & FDR & 10th Cir. & $5 / 29 / 1968$ & Warren & $10 / 30 / 1975$ & $5 / 29 / 1968$ \\
\hline Edwin A. Robson & Eisenhower & IL-N & $5 / 29 / 1968$ & Warren & $7 / 1 / 1979$ & - \\
\hline ooling Minor Wisdon & tiserbower & 5 th 6 . & $5 / 29 / 1968$ & Warren & $11 / 15 / 1978$ & $1176 / 1995$ \\
\hline Joseph S. Lord, III & JFK & $P A-E$ & $5 / 29 / 1968$ & Warren & $7 / 17 / 1978$ & - \\
\hline William H. Becker & JFK & MO-W & $5 / 29 / 1968$ & Warren & $2 / 1 / 1977$ & - \\
\hline Andrew A Calfrey & Ersennoner & Mn & 1161975 & Burger & 6111990 & 22011980 \\
\hline Roy W. Harper & Truman & MO-E & $2 / 1 / 1977$ & Burger & $9 / 30 / 1983$ & - \\
\hline Charles R Vemer & $\mathrm{BI}$ & PAE & $10 / 25 / 978$ & Bunger & $9 / 3011983$ & 2 \\
\hline Murray J. Gurfein & Nixon & 2nd Cir. & $11 / 15 / 1978$ & Burger & $12 / 16 / 1979$ & $11 / 15 / 1978$ \\
\hline Sam C. Pointer & Nixon & $A L-N$ & $3 / 1 / 1980$ & Burger & $12 / 7 / 1987$ & - \\
\hline S. Hugh Dillo & $F x=$ & $N-S$ & $1011 / 1983$ & Burger & 1012611992 & - \\
\hline Louis H. Pollack & Carter & PA-E & $10 / 1 / 1983$ & Burger & $10 / 26 / 1992$ & - \\
\hline Milon Pollak & 181 & NIS & $10 / 1 / 1983$ & Burger & $11 / 3071994$ & - \\
\hline Halbert 0. Woodward & [B] & TX-N & $3 / 8 / 1989$ & Rehnquist & $6 / 23 / 1992$ & - \\
\hline Johin I Nangle & Nixon: & Mo $E$ & $6 / 1 / 1990$ & Rehoruist & $12 / 1 / 2000$ & $6 / 11990$ \\
\hline Robert R. Merhige, Jr. & LBJ & VA-E & $11 / 19 / 1990$ & Rehnquist & $6 / 8 / 1998$ & - \\
\hline Willan B Enright & Nixon & CAS & $1119 / 1990$ & Rehinuist & $6 / 1 / 2000$ & thes \\
\hline Barefoot Sanders & Carter & TX-N & $10 / 26 / 1992$ & Rehnquist & $6 / 1 / 2000$ & - \\
\hline Glarenee A Bimmer & nord & $x y=$ & 1072611992 & Rehruuist & 6112000 & 醇 \\
\hline Wm. Terrell Hodges & Nixon & FL-M & $6 / 1 / 2000$ & Rehnquist & $6 / 13 / 2007$ & $12 / 1 / 2000$ \\
\hline Q. Iowell lensen & Reagan & CAN & 12112000 & Rehnquist & $06 / 01 / 2008$ & 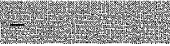 \\
\hline J. Frederick Mot2 & Reagan & MD & $7 / 13 / 2001$ & Rehnquist & $06 / 01 / 2009$ & - \\
\hline Robert L Miler ir & Reagan & WN & $1 / 12003$ & rehroulst & 1011521010 & S- \\
\hline Kathryn H. Vratil & H. W. Bush & KS & $2 / 2 / 2004$ & Rehnquist & NA & - \\
\hline Oavid R ransen & $1 \mathrm{~N} \cdot \mathrm{Bu}$ sh & $8+1611$ & $719 / 2004$ & Rehiguist & $05101 / 2014$ & $=$ \\
\hline Anthony J. Scirica & Reagan & 3rd Cir. & $6 / 1 / 2006$ & Roberts & $06 / 15 / 2008$ & - \\
\hline lahn G Heyhurill & 1N Bush & nen & $6 / 14,2007$ & Robiets & $N A$ & 61412007 \\
\hline W. Royal Furgeson & Clinton & TX-W & $09 / 22 / 2008$ & Roberts & NA & - \\
\hline Fraill o, banret, I) & Anton & CAt & $2109 / 2008$ & Robers & $10115 / 201$ & 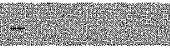 \\
\hline David W. Trager & Clinton & NY-E & $10 / 07 / 2009$ & Roberts & $04 / 01 / 10$ & - \\
\hline Babara S. Jones & Clinton & AYS & $05 / 212010$ & Roleres: & $10175 / 2012$ & $=-2$ \\
\hline Paul J. Barbadoro & H. W. Bush & $\mathrm{NH}$ & $11 / 08 / 2010$ & Roberts & NA & - \\
\hline Mavicie O Rendel & Clintor & 3d G G & $05 / 242011$ & Roberts & NA & te \\
\hline Charles R. Breyer & Clinton & CA-N & $10 / 16 / 2011$ & Roberts & NA & - \\
\hline Kevis A Kaplan. & Clinton & NYS & $10 / 24 / 2012$ & Rolerts & NA: & 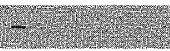 \\
\hline
\end{tabular}




\section{-}

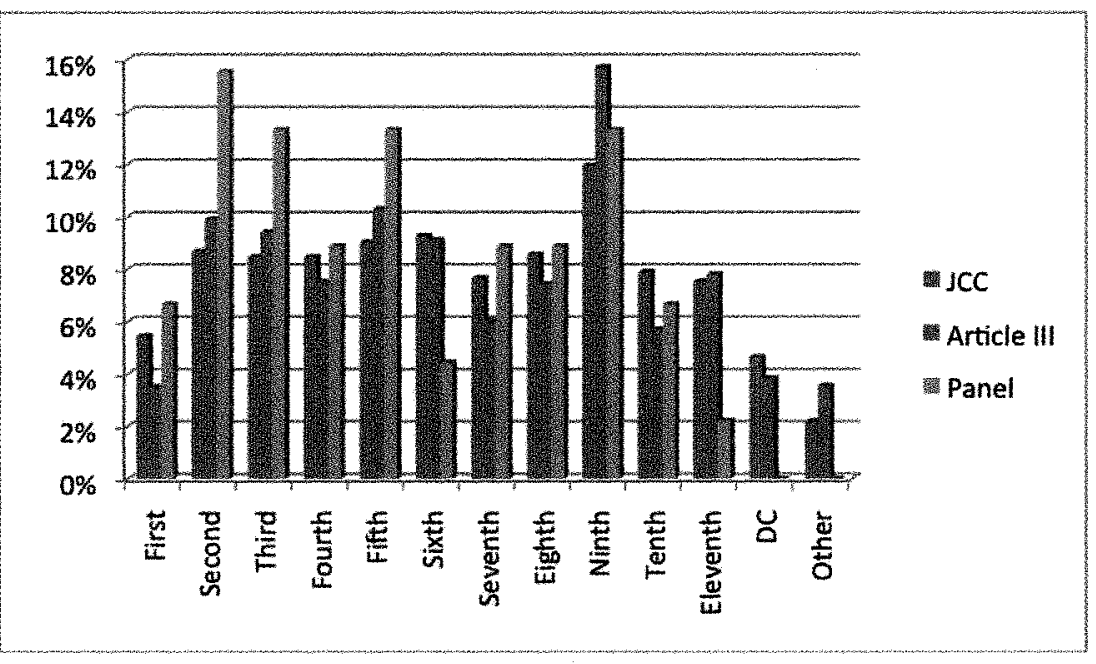

tial appointees, have served as chief justice since the creation of the MDL Panel: Chief Justices Warren, Burger, Rehnquist, and Roberts. Judicial Conference Committee data is available for only the last three chief justices.

Chief Justice Rehnquist's appointments dominate our data, which is not surprising since he served as chief for nearly half of the period. Chief Justice Warren appointed the original seven MDL panelists (15\%), Burger appointed $11(24 \%)$, Rehnquist 18 (39\%), and Roberts $10(22 \%)$. The data for the Judicial Conference Committee appointments begins in 1971 with Chief Justice Burger. ${ }^{19}$ Burger appointed 74 of the Conference members (8.6\%), Rehnquist appointed 652 (75.7\%), and Roberts appointed 135 (15.7\%).

\section{Circuit Variation}

The chief justice may appoint any district or appellate judge to serve on the Panel but is limited to one from each circuit at any time. This requirement has resulted in a more even distribution of Panel members across the circuits than we might otherwise see. Figure 1 shows the percentage of MDL Panel judges from each circuit compared to the percentage of Judicial Conference Com- mittee members and the percentage of all Article III judges. ${ }^{20}$ The Second Circuit has had the largest number of judges (seven) on the MDL Panel. The Sixth and Eleventh have had only two judges on the MDL Panel, and the D.C. Circuit has had none.

Another way to view circuit representation is by looking at the MDL Panel over time. The Ninth Circuit has had a judge on the panel for 99 percent of the Panel's life. Excluding those periods when a Panel seat is empty, the MDL Panel lacked a Ninth Circuit representative for only one 183-day period between the service of Judge Enright and Judge Jensen. Looking at the table, it is clear that appointment is not randomly distributed across the circuits with some, like the Third and Fifth, represented for most of the Panel's existence

19. Judicial Conference Committee service dates are listed by year, but changes in chief justice can occur throughout the year. For example, Chief Justice Rehnquist started his tenure in September 1986 and died in September 2005. The Administrative Office does not record the name of the chief justice who appointed committee members, thus we had to decide how to treat members appointed in a year with two different chiefs. We opted to assign based on which chief was in office the majority of the year, and thus we assigned 1,986 appointments to Chief Justice Burger and 2005 appointments to Chief justice Rehnquist. while others, like the Sixth or D.C. Circuits, participating only briefly, if at all. Given the importance of circuit representation to case transfers, the variation in representation is noteworthy. ${ }^{21}$ That is, the Panel is more likely to transfer a case to a court represented on the Panel.

The seven Panel chairs have come from seven different circuits. No Panel chair has been a judge in the Third, Fourth, Seventh, Ninth, or D.C. Circuits. The lack of a Third or Ninth Circuit Panel chair is most surprising given the considerable role both have played in the MDL Panel's history. Moreover, each circuit has had a large number of MDL cases.

\section{Judicial Experience}

Judicial experience includes the court on which a judge serves, length

20. At the time Judge Pointer was appointed to the Panel, the Northern District of Alabama was in the Fifth Circuit. Shortly after his appointment, the Eleventh Circuit was created. Since we rely on characteristics at the time of selection for the MDL Panel, Pointer is counted in the numbers for the Fifth Circuit in Figure 1. Judge Gibbons was elevated to the Sixth Circuit (from the Western District of Tennessee) while she was a Panel member. While she sat on two courts during her Panel tenure, her presence in the Sixth Circuit is only counted once in Figure 1.

21. Williams \& George, supra note 3. 
of tenure as a judge, and the nature of a judge's caseload. As we explain below, the judicial experience of judges of the MDL Panel varies in significant ways from that of the judges of the Judicial Conference and of the full Article III judiciary. We find that district judges make up an even larger percentage of the MDL Panel than we would predict based on their representation in Conference Committees and the Article III courts as a whole. ${ }^{22}$ MDL Panel judges have served on the bench much longer before appointment than Conference Committee judges. Finally, we find that MDL Panel judges are more likely to have MDL litigation experience, with much of that experience gained after appointment to the Panel.

Both the MDL Panel and the Judicial Conference Committees are dominated by district judges, consistent with the relative composition of the Article III judiciary. Between 1968 and 2012, district judges accounted for 82 percent of the entire Article III judiciary and outnumbered circuit judges by more than five to one. ${ }^{23}$ of the 46 members of the MDL Panel, 85 percent were sitting district judges at the time of appointment (39), while 15 percent were appellate judges (7). Circuit judges were better represented on Conference Committees than their total numbers would predict, but district judges still outnumbered circuit judges by a margin of three to one. ${ }^{24}$ Thus, district judges have been slightly overrepresented on the MDL Panel and underrepre-

22. These figures are based on the court of service at the time of appointment to the MDL Panel or Conference Committee.

23. Between 1968 and 2012, 1,977 judges served on district courts, 371 judges served on circuit courts, 15 judges served on the Supreme Court, and 54 judges served on specialized Article IIl courts.

24. Of the 861 judges appointed to Conference Committees between 1971 and 2012, 635 were sitting district judges (73.8\%), 219 were circuit judges (25.4\%), and seven were specialized court judges $(0.8 \%)$.

25. Because these times are estimated from the first court on which the judge served during the period, we are overestimating the time of service slightly. A better comparison is to consider the time in the position in which the judge served when appointed to the Conference Committee seat. Again, the range was from zero to 50 years, and the average time of service was sented on Conference Committees.

Multidistrict litigation is focused on case management and pretrial litigation, making federal trial judges a logical choice for the MDL Panel. If we look at service prior to appointment to the MDL Panel, 98 percent of Panel judges had experience on the district court. Just one MDL Panel judge had served only on the court of appeals. By comparison, 18 percent of Conference Committee judges had never served on the district bench. The difference likely reflects a need to appoint experienced trial judges to the Panel.

The chief justice also is more likely to select judges with longer tenures on the bench to serve on the MDL Panel than on the Conference Committees. Committee judges, on average, served approximately eight years before appointment with a range of zero to 50 years. (The most common length of service [mbde] was four or five years before appointment to a committee. ${ }^{25}$ J Judges on the MDL Panel also had varying lengths of tenure before appointment-between five and 31 years of service. But they served on average almost twice as long as Conference Committee judges (16 versus 8.4 years) before appointment to the MDL Panel. ${ }^{26}$

The disproportionate number of district judges and more senior judges appointed to the MDL Panel may reflect an effort to select judges who had experience with complex litigation and, in particular, multidis-

slightly less, at 7.9 years. The modal time to appointment was four years.

26 . In considering the time a judge spends in the seat where they serve at the time of appointment to the MDL Panel we see a slightly different pattern The average time spent is 15.5 years, again raised by outliers such as Judges Hodges and Murrah, who served several decades before appointment to the MDL Panel. The range of service times is smaller, with one judge, Judge Gurfein, serving four years on the Second Circuit before appointment to the MDL Panel. Overall, appointment to the $\mathrm{MDL}$ Panel appears to take twice as long as appointment to the Judicial Conference Committees.

27. Three cases were consolidated before multiple judges and are excluded from this analysis because they were exceptional cases. Within the life of an MDL, cases are transferred to other judges for a variety of reasons. Our focus is on the judge initially assigned to the MDL at the time of consolidation. trict litigation. While not required, such experience is certainly one rationale for specialization. The conventional wisdom is that chief justices appoint panelists with MDL experience. Chief Justice Warren, who recommended the creation of the Panel and named the original seven panelists, picked four judges involved in the electrical equipment litigation, which gave rise to the MDL Panel. Three served on the Coordinating Committee: Its chair, Judge Murrah, became the first Panel chair, and two members, Judges Becker and Robson, joined him. A fourth appointee, Judge Lord, tried several of the cases. Subsequent chief justices would be able to name judges who handled MDL cases created under the statute. The question is whether they did so.

The great majority of Article III judges have never served as an MDL transferee judge. Between 1968 and 2012, 1,465 multidistrict actions were consolidated before 779 different judges. ${ }^{27}$ Thus, one-third of Article III judges had been assigned at least one MDL. A few judges handled multiple MDLs. At the high end, District Judge Charles Weiner managed 15 MDLs over his long career, which included time on the MDL Panel. On average, a judge serving between 1968 and 2012 handled 0.62 MDLs. That average decreased to 0.58 if the judge never served on the MDL Panel.

The foregoing figures include all Article III judges since any Article III judge can serve as a transferee judge, but nearly all MDL assignments are made to district judges. Only two circuit judges have served as MDL transferee judges. Figure 2 shows MDL experience for all district judges. On average, a district judge serving during this period handled 0.75 MDLs. Forty percent of district judges have been assigned an MDL.

We would expect chief justices to appoint judges with prior MDL experience to the MDL Panel. But judges appointed to the MDL Panel are only slightly more likely to have had prior MDL experience than judges not appointed. Of the 46 MDL Panel judges, only 25 had MDL experi- 
ence when appointed; that is, 52 percent of MDL appointees had prior MDL experience as compared to 40 percent of all judges. If we focus only on district judges, who are more likely to have MDL experience, district judges appointed to the MDL Panel averaged 0.94 MDLs while all district judges averaged 0.75 .

MDL Panel members frequently gain MDL experience after joining the Panel. If we look at their entire service including time on the Panel, MDL panel judges average 2.5 MDLs. This higher average reflects the experience of eight members, including three original panelists, who were not assigned any MDLs. Seven of those eight judges served as circuit judges, and one of the seven had no district court experience and thus was unlikely to be an MDL transferee judge. Figure 3 shows the variation in MDL experience among all Panel members (both district and circuit judges). Figure 4 shows the assignments for district judges only. The average number of assignments to district judges on the MDL Panel is 2.8 .

Chief Justice Roberts appears to have placed more importance on prior MDL experience than his predecessors. Warren, of course, had no opportunity to appoint a judge with prior MDL experience, as the Panel was created during his tenure. Not surprisingly, as MDL experience has grown within the judiciary over time, so has the average experience for the chief justices' appointees to the Panel (though not linearly). Burger's appointees averaged $0.81 \mathrm{MDLs}$ prior to appointment, while Rehnquist's appointees averaged 0.67 MDLs and Roberts's averaged 1.7. With the small number of appointees for any chief justice, the averages are highly subject to the influence of outliers. Chief Justice Roberts, for example, appointed Judge Breyer, who had more prior MDL experience than any other Panel member in history (11 MDLs). (Judge Weiner gained some of his experience after being appointed to the Panel.)

Most judges, even most district judges, do not have experience as
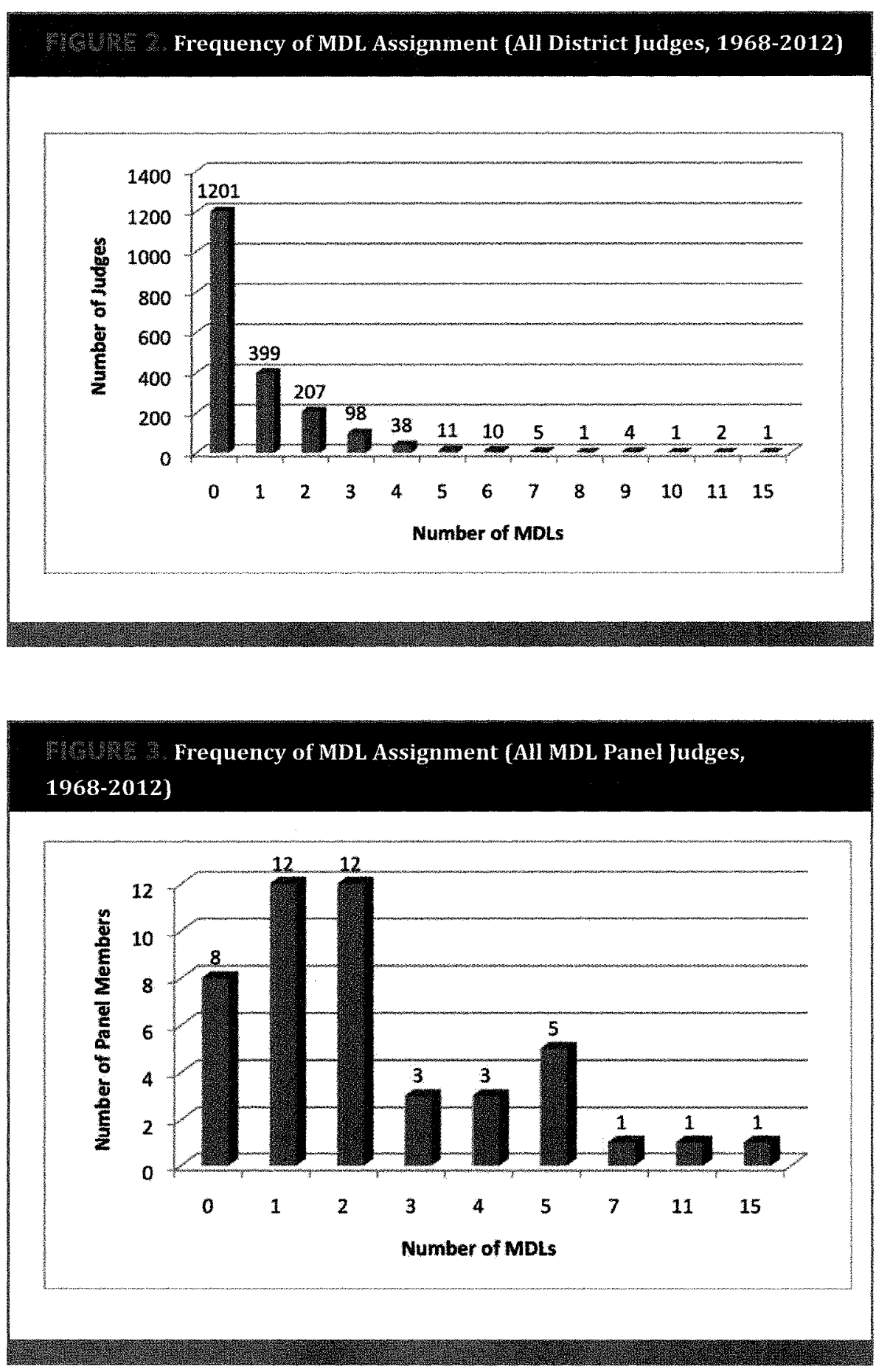

MDL transferee judges. Panel judges clearly gain that experience, but many join the Panel without any experience managing an MDL. The emphasis placed on the complex litigation experience of Panel members, while still important to the MDL process, may be overstated. Given that the amount of MDL experience has changed for Panel members over time, it is likely that other character- istics have changed as well. We now turn to an examination of other characteristics of Panel members relative to the rest of the judiciary and the Judicial Conference.

\section{Appointing President}

Article III judges are appointed by the president with the advice and consent of the Senate. Given the frequency of divided government, it is 


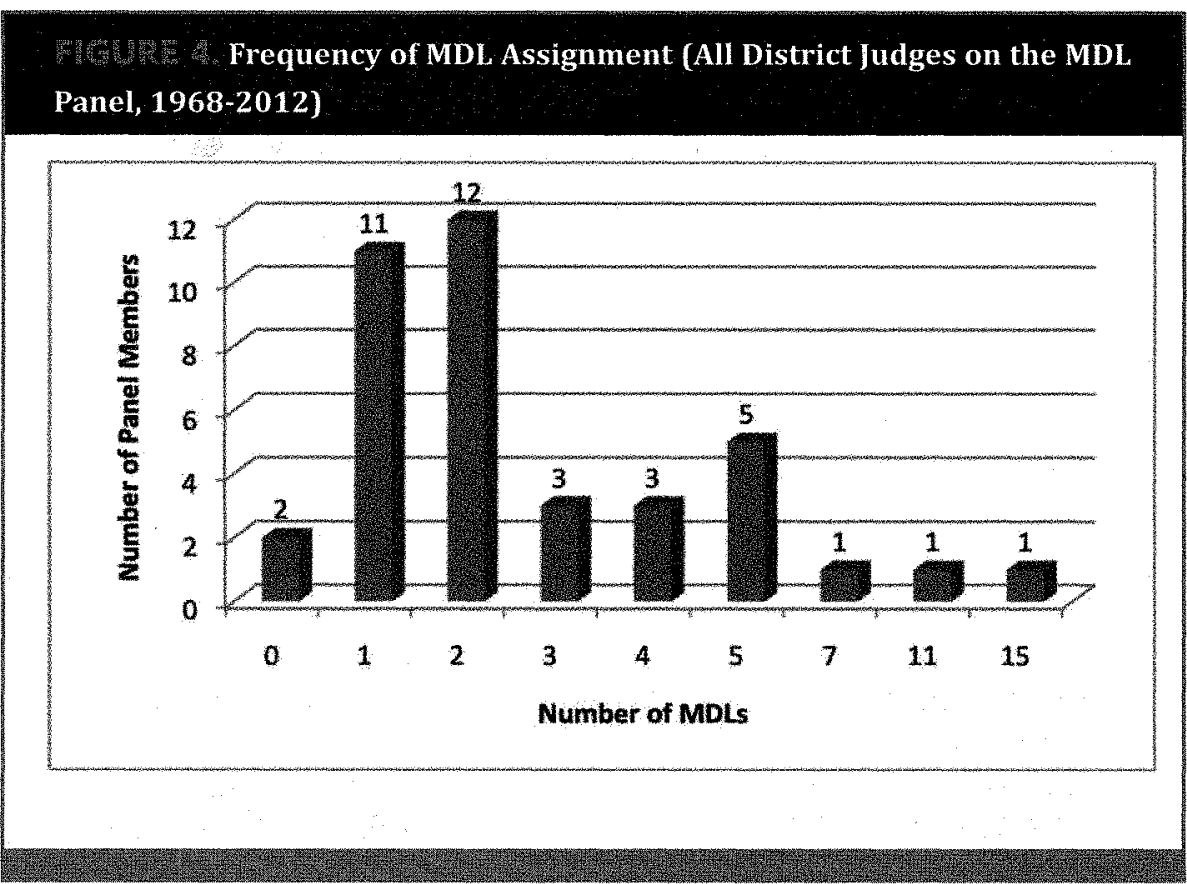

\begin{tabular}{|c|c|c|c|}
\hline Chief Justice & Panel Members & $\begin{array}{l}\text { Judicial } \\
\text { Conference } \\
\text { Members }\end{array}$ & $\begin{array}{l}\text { Article III } \\
\text { Judges } \\
\text { (Averages) }\end{array}$ \\
\hline \multicolumn{4}{|l|}{ Warren (1968) } \\
\hline Democratic Appointees & $5(71 \%)$ & - & $405(73 \%)$ \\
\hline Republican Appointees & $2(29 \%)$ & - & $149(27 \%)$ \\
\hline $\begin{array}{l}\text { Burger }(1969) 1986) \\
\text { Demorran Appontees } \\
\text { Republican Appointees }\end{array}$ & $\begin{array}{l}7(64 \%) \\
4(36 \%)\end{array}$ & $\begin{array}{l}3.442 \%) \\
43(58 \%)\end{array}$ & $\begin{array}{l}885(55 \%) \\
320(45 \%)\end{array}$ \\
\hline \multicolumn{4}{|l|}{ Rehnquist (1987-2005) } \\
\hline Democratic Appointees & $3(17 \%)$ & $264(40 \%)$ & $453(43 \%)$ \\
\hline Republican Appointees & $15(83 \%)$ & $388(60 \%)$ & $588(57 \%)$ \\
\hline \multicolumn{4}{|l|}{ 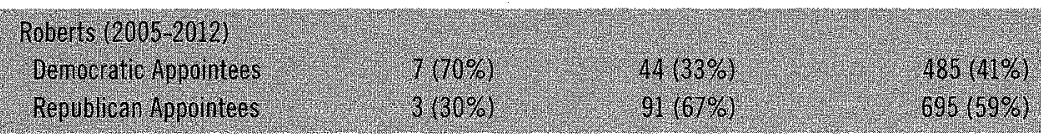 } \\
\hline \multicolumn{4}{|l|}{$A L L$} \\
\hline Democratic Appointees & $22(48 \%)$ & $339(39 \%)$ & $1,728(50 \%)$ \\
\hline Republican Appointees & $24(52 \%)$ & $522(61 \%)$ & $1,752(50 \%)$ \\
\hline
\end{tabular}

not surprising that we find the judiciary almost evenly split during the 1968 to 2012 period: 1,172 judges (48.5\%) were initially appointed by Democratic presidents, and 1,245 (51.5\%) by Republican presidents. The MDL Panel also is evenly divided between judges appointed by Democrats and those appointed by Republicans: $22(47.8 \%)$ were appointed by Democrats while $24 \quad(52.2 \%)$ were appointed by Republicans. The Judicial Conference Committees, however, have been less balanced:
$340(39.5 \%)$ were initially appointed by Democrats as opposed to 521 $(60.5 \%)$ by Republicans. (These numbers include every appointment made by a chief justice even if the judge has prior service.)

As reflected in Table 3, our analysis of the data suggests that neither the appointments to the MDL Panel nor to the Judicial Conference Committees have been evenly balanced by partisanship. (Judges who have served on more than one committee are recorded only once in Table 3.) of course, they are constrained by the composition of the Article III courts, which is set forth in the last column. Chief Justice Warren's appointments to the Panel, like the Article III courts at the time, were overwhelmingly Democratic presidential appointees. On the other hand, Chief Justices Burger and Roberts both named Democratic appointees to the MDL Panel at a rate higher than their numbers on the bench (and also at higher rates than their appointments to committees). Chief Justice Rehnquist was much more likely to name Republican appointees, and his appointments produce the partisan balance we observe in the Panel as a whole.

\section{Gender and Race}

Most federal judges have been white men. Franklin Roosevelt appointed the first woman to an Article III court in 1934, and only six had served by 1968 , when the Panel was created. But the growth since that time has been dramatic: 342 women, i.e., 14.1 percent of all judges, have served on Article III courts (through 2012). Women have made up a relatively larger portion of Conference Committee appointees: 152 out of $861(17.7 \%)$. The MDL Panel, however, has had few women members: only four of the 46 Panel judges (or $8.7 \%$ ). Recent MDL appointments suggest that female representation is trending up: Four out of the 18 appointments since 2000 , when the first woman was named, have been women (22.2\%). As has already been demonstrated, the importance of experience on the 
bench is likely part of the reason for the low numbers of women on the JPML. Female judges really grew in number during the Carter years, but with an average of 16 years of service for any judge before joining the JPML, it was not until 1996 that a sufficient number of women had the average level of experience to join the JPML. The first appointment of a woman in 2000 is close to this timeframe.

The federal judiciary has also become an increasingly racially diverse institution since 1968. Nearly 13 percent of judges selfidentified as a member of a racial or ethnic minority. A similar percentage $(12 \%)$ of Judicial Conference Committee judges self-identified as a minority. But every MDL Panel judge has self-identified as white.

The gender and racial breakdown of each group is easier to see in Table 4 (for women) and Figure 5 (for racial minorities). To avoid over-counting, the numbers reflect initial appointment. Thus, if a judge were elevated, she is only reported for her first court. Justice Sotomayor, for example, is recorded as a Latina appointed to the district court but not counted in numbers based on her subsequent service on both the appellate court and the Supreme Court. Specialized courts are Article III courts to which the judge is appointed, such as the U.S. Court of International Trade (and its predecessor, the U.S. Customs Court).

The variation by chief justice in appointing women and minorities to the JPML or the Judicial Conference is also interesting. Table 5 shows the variation by chief justice, along with the important comparisons of the Article III courts as a whole. ${ }^{28}$

We would expect to see a change in the racial composition of the MDL Panel for several reasons. First, the Article III judiciary has diversified dramatically, as reflected in Table 5. Furthermore, the current chief justice's rate of appointment of minorities to the Judicial Conference Committees is high. Finally, minority judges are gaining experience

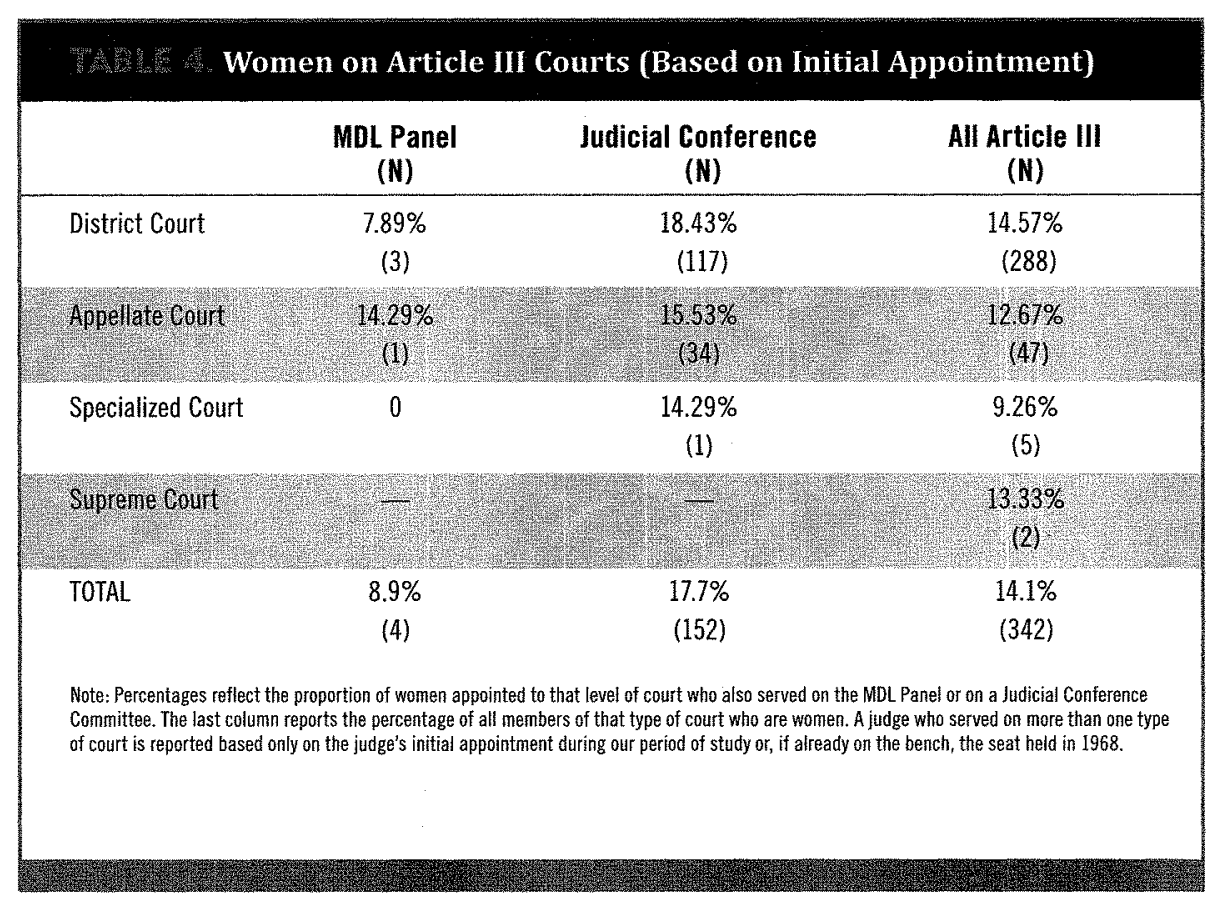

Racial Minorities on Article III Courts (Based on Initial

\section{Appointment]}
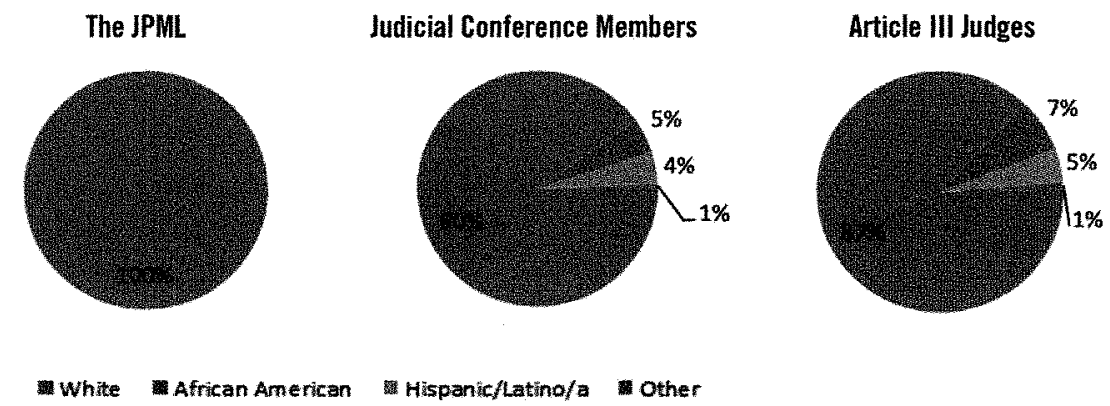

White

Note: Calcutations are based only on judges who reported a race. Percentages refiect the proportion of minorities appointed to that level of court who also served on the MDL Panel or on a Judicial Conference Committee. The "Other" category includes judges who self-identify as Asian American, American indian, or more than one race. The last column reports the percentage of all members of that type of court who are minorities. A judge who served on more than one type of court is reported based only on the judge's initial appointment during our period of study or, if alieady on the bench, the seat held in 1968 .

in multidistrict litigation. The MDL Panel has assigned consolidated MDL cases to 96 different minority judges, but most of these assignments occurred since 1990. By the end of 2012, one-third of minority judges had managed an MDL. Currently there are 60 minority district judges who have served as an MDL transferee judge. The increased experience with multidistrict liti- gation and with experience in the federal courts generally makes the appointment of a minority judge to the JPML increasingly likely.

28. We group race into white and non-white for purposes of this table to make the comparison easier. The total number of Conference Committee appointments by race does not total to 861 because of missing information on some judges. 


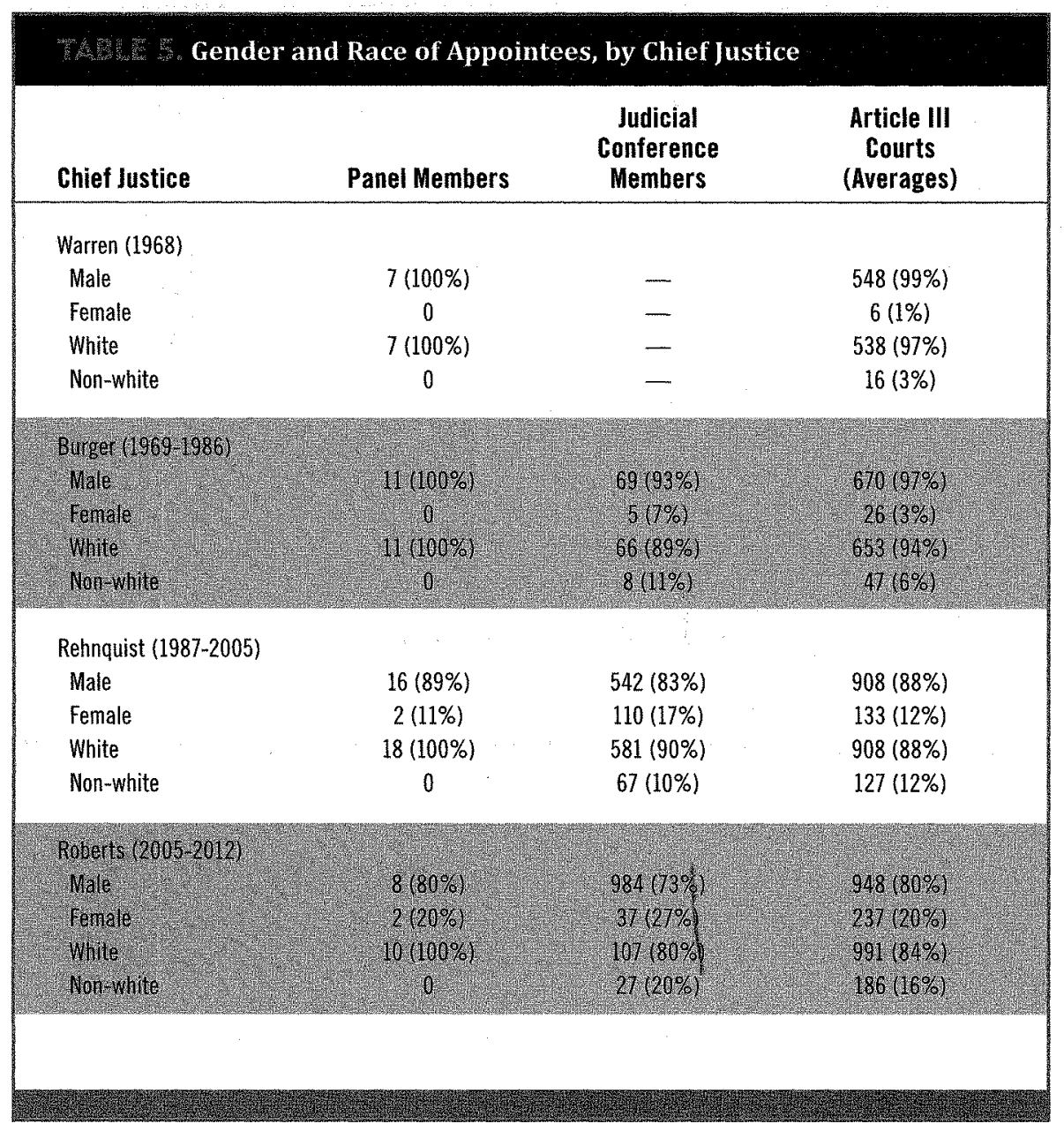

\section{Conclusion}

The JPML was created to provide a forum where decisions about coordination of complex issues could be decided. This Panel, initially comprised of members with aboveaverage experience with complex litigation, continues to serve as an area of expertise in complex litigation today. Judges who serve on the Panel have more experience with complex litigation than the rest of the Article III judges. The majority of this experience, however, comes with service on the Panel. While on average Panel members serve as transferee judges for more cases than the rest of the judiciary, they are still more likely than not to join the Panel without MDL experience. So while complex litigation experience is clearly relevant to Panel appointment for the chief justice choosing Panel members, it is not the whole story.

Comparing Panel members with judges, or those with district-judge experience, to serve on the Panel is not surprising. The Panel oversees the coordination of the litigation at the trial level, and trial-court experience would be invaluable to the consolidation decision. Likewise, longer tenure on the bench would likely serve the judge well, giving her more experience to understand the problems of complex litigation and the potential benefits of coordination. Of course, longer tenure also serves judges on the Judicial Conference Committees well, as a greater understanding of the administrative structure of the courts and its needs is more likely to come over time. It is perhaps this need for substantial experience that explains lower levels of participation by women and minorities on the JPML than we find in the Judicial Conference Committees or the federal judiciary as a whole.

Given the importance of the chief justice in making appointments to the JPML, it is important for future research to consider his influence in greater depth than explored here. Scholars and commentators recently have been interested in the extent to which the chief justice serves his own policy goals through the power of appointment. It is possible that appointments to the JPML serve similar goals. In demonstrating the strong variation among judges serving on the JPML, this article provides a strong foundation for such future endeavors. * sion among Panel members is even more surprising when compared with the members of the Judicial Conference Committees and the rest of the judiciary from which the chief justice makes appointments.

With partisanship mattering less than the rest of the literature on judicial appointments would suggest, one might think that other characteristics of judges are also balanced, but this is not the case. Some differences in membership among appointments to the Panel, the Conference Committees, and the Article III courts are easier to explain than others. For example, the preference for district
TRACEY E. GEORGE

is Professor of Law, Professor of Political Science, Tarkington Chair in Teaching Excellence, and Director of the Branstetter Litigation and Dispute Resolution Program at Vanderbilt University.

(tracey.george@Law.Vanderbilt.Edu)

\section{MARGARET S. WILLIAMS}

is Visiting Scholar at Vanderbilt Law School. (mswilliams77@gmail.com) 